Teresa Marie Derrick-Mills

\title{
Exploring the Dimensions of Nonprofit Competition through its Supplementary, Complementary, and Adversarial Relationships with Government
}

\begin{abstract}
Nonprofits contribute to communities and society through service delivery, innovation, knowledge-building, and civic engagement. They frequently partner with and push government to better serve its citizens through relationships that have been characterized as supplementary, complementary, and adversarial (Young 2006). In all of these roles and relationships, nonprofits must compete for resources, time, and attention with other nonprofits, government entities, and forprofit organizations within communities, nationally, and internationally. Competition sometimes shapes and sometimes is shaped by public policies that affect the rules of the game. In this conceptual paper, we explore the dimensions of nonprofit competition and the implications for the nonprofit-government supplementary, complementary, and adversarial relationships.
\end{abstract}

Keywords: nonprofits,competition, complementary, supplementary, advocacy

\section{Introduction}

According to the National Center for Charitable Statistics (NCCS), there are 1.4 million nonprofits of many shapes and sizes in the United States (NCCS Business Master File 2013). In this conceptual paper, I explore the dimensions of nonprofit competition and the implications for the nonprofit-government complementary (aligned), supplementary (independent), and adversarial (change) relationships. I take a broad view of nonprofits rather than focusing on a specific type of nonprofit or a particular policy area to examine the scope and breadth of competition facing nonprofits. My conceptualization suggests the need for empirical studies that explore whether nonprofit competition is beneficial for

Teresa Marie Derrick-Mills, Center on Nonprofits and Philanthropy, Urban Institute, Washington, DC, USA, E-mail: tderrick-mills@urban.org 
society through the dimensions of competition and the nonprofit-government relationship. Nonprofit competition may foster more efficiency or effectiveness; stimulate more discussion, innovation, and knowledge; and, it may engage citizens more in their society. But, it may not. Competition may impede or foster collaboration. The point is that we do not know the impacts of competition without systematically studying it.

This paper is structured as follows. First, I introduce the concepts of government-nonprofit relationships and competition. Next I provide an overview of our conceptual framework dimensions. The bulk of the paper is spent exploring the competition dimensions, especially as they relate to government-nonprofit relationships. I conclude with implications of competition for government-nonprofit relationships and suggestions for further research on the dimensions and implications of nonprofit competition.

\section{Complementary, Supplementary, and Adversarial Government-Nonprofit Relationships}

The complementary, supplementary, and adversarial nonprofit-government relationships framework developed by Young (2006) creates a useful lens for examining the competitions in which nonprofits engage (see Table 1). As characterized by Young (2006), nonprofits help improve society through their relationships with government in three primary ways. Nonprofits partner with government to provide more of what it has defined that society needs (complementary). Nonprofits fulfill societal demands not currently being met by government (supplementary). Finally, nonprofits help governments improve society through an adversarial relationship whereby nonprofits identify government policies or resource allocation strategies that do not match the needs of society and strive to change them; many would refer to actions in this category as advocacy. In this paper, I have renamed the three nonprofit-government relationships as aligned (representing complementary), independent (representing supplementary), and change (representing adversarial).

In each of the three distinct roles, nonprofits have important contributions to make in strengthening society which may be hindered or helped by competition. The particular type of relationship with government also shapes the competition space of nonprofits through the rules and regulations that define the nonprofit sector (primarily tax laws); the rules, regulations, and standards that shape government-mediated grant and contract competitions and awards; and, the policy and budgetary decisions that determine resource allocations for government funding. Thus, the framework provides a mechanism for teasing out 
Table 1: Nonprofit-government relationships.

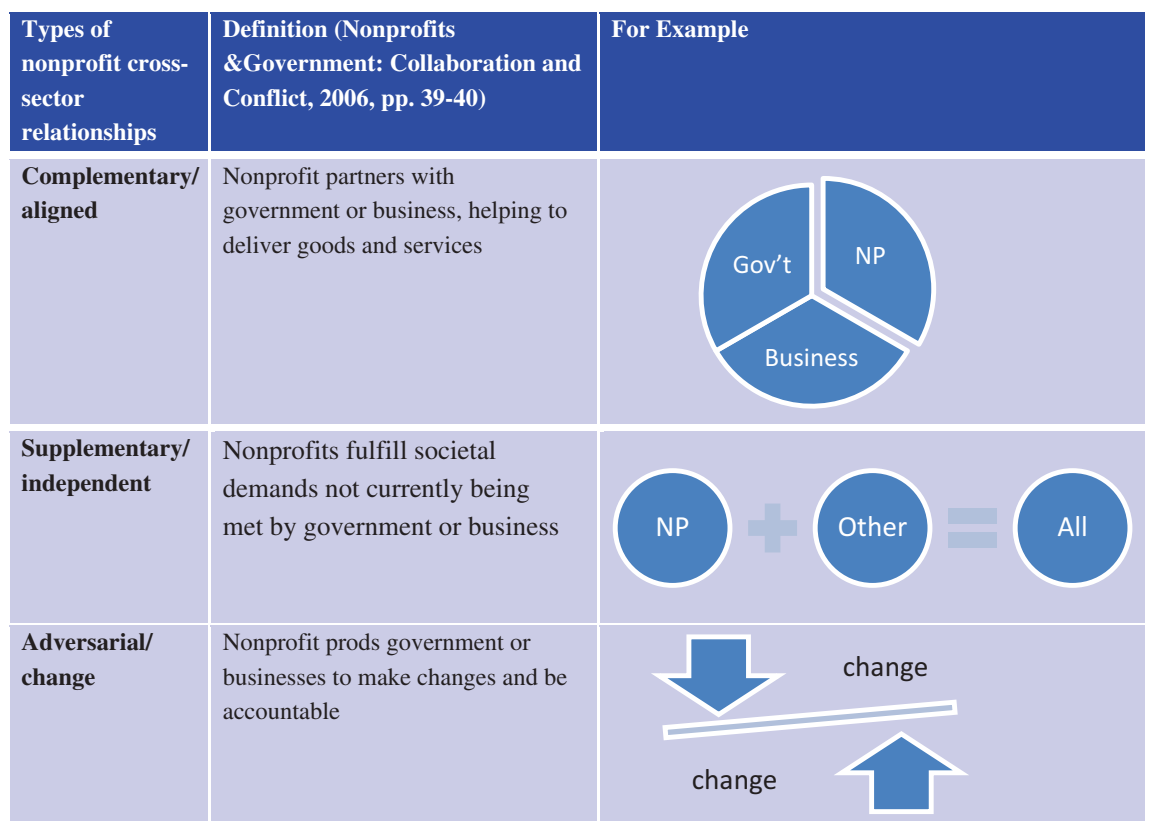

the many angles of competition in a way that helps us to understand the "so what?" or impact of the competition for the individual nonprofit and for society as a whole.

\section{Types of Competition}

When thinking of competition, typically the description of free market competition is what comes to mind. There are other types of competition, however, that must be considered when discussing the competitive environment of nonprofits. Governments and other funding intermediaries sponsor competitions to accomplish their goals.

In the United States, the standard of an efficient economy - and therefore efficient delivery of goods and services - is based on the concept of a competitive marketplace (Wiemer and Vining 2005). In this market, producers of goods and services compete to provide just the right amounts of goods and services at just the right prices to the consumers that purchase them. If producers are not able to price their goods and services at rates that consumers are 
willing to pay, or if they do not produce goods or services that consumers want, then they go out of business. Essentially, the consumers decide which products and services will exist, and which firms will deliver them based on their willingness to pay.

Theoretically, competitive markets are the most efficient means of providing goods and services; however, these markets have failures that compromise their ability to provide all the goods and services a society desires. For example, a society may want to ensure that its citizens have food, housing, and education even if they cannot afford to pay what it costs to produce these goods and services. So, the government steps in to either deliver the desired goods and services directly, to foster the delivery of those goods and services, or to provide vouchers so that consumers can make market choices.

When the government decides to take the service delivery route, it creates the parameters of the market by designing the rules, regulations, and performance standards for competition. Then, it determines which organizations are eligible to compete for the delivery of these goods and services; these organizations may be nonprofit organizations, for-profit organizations, and other governments. Competition that is initiated by and decided through the institutions of government is called mediated competition (Kincaid 1991). This type of government-mediated competition has been common in the delivery of local government services since the 1990s when the reinventing government movement was popularized by the work of Osbourne and Gaebler (1992). That movement borrowed from the principles of the for profit arena to suggest that government would be more efficient if it had to compete with other entities to provide its own services.

At the federal level, the government has begun to foster more competition to improve social policy outcomes. It is mediating these competitions in both longterm programs like the US Department of Health and Human Services' Head Start, and new initiatives to stimulate or scale innovation as in the US Department of Education's i3 Program and the Corporation for National and Community Service's Social Innovation Fund (SIF). In the case of Head Start, the government is introducing competition for existing grantees that do not meet new performance benchmarks in terms of the quality of services they are delivering for low-income children and families. The i3 and SIF programs, on the other hand, are designed as competitions to foster new ideas and solutions and to take to scale solutions and programs that have an evidence base. All three of these competitions involve competition within the nonprofit sector, but they also encourage collaboration within and across sectors.

A third type of competition exists that mirrors the characteristics of the government-mediated competition. The difference is that this third type is 
initiated by and decided through non-governmental funders. These funders include nonprofit intermediary organizations like United Ways, foundations, and businesses. Like government, these funders have goals they want to accomplish and resources they can provide, but organizations must compete to obtain these resources. As indicated by Frumpkin and Andre-Clark (2000): "Nonprofits must compete aggressively for these funds by committing to specified outcomes within their proposals. Few organizations are in a position to demand either a greater autonomy or a relaxation of grant guidelines" (p. 143).

Thus, there are at least three types of markets in which nonprofits may compete. The "pure" market where they compete for the beneficiaries/ consumers of their services and private donations, the government-mediated market where they compete for government funds to meet needs as defined by government, and the other funder-mediated market where they compete for foundation or business support to help those organizations accomplish their goals. These markets represent externally identified needs and sets of goals. Nonprofits also have their own missions and goals and are identifying the needs of the communities they serve as they emerge. That means that they must compete in the space between the markets to surface the new needs and identify funders - perhaps individual donors - to support services in that space. Figure 1 illustrates the complex configuration of markets and competition in which the nonprofits engage. The area inside the bold line represents nonprofit competition, but the area outside the bold line recognizes that for profit businesses and governments are also competing in these spaces.

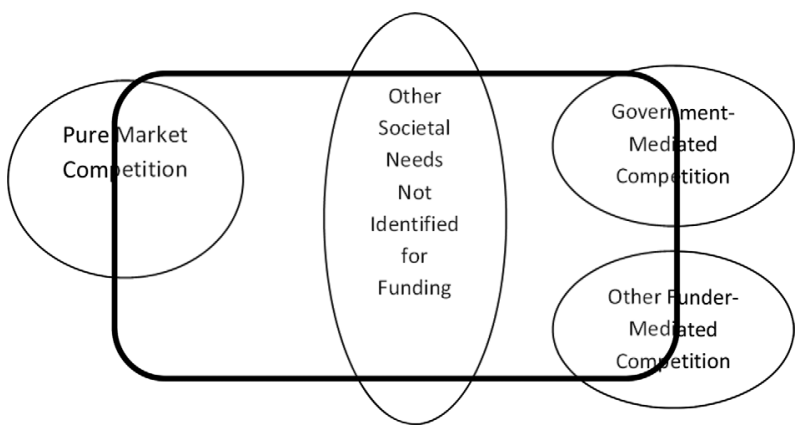

Figure 1: The nonprofit competition space.

\section{Competition and Collaboration}

This discussion of competition is not meant to suggest that there is not also collaboration within the nonprofit sector and across the nonprofit, for profit, and 
government sectors. Nonprofits are competing and collaborating and sometimes with the same entities. As a study by Lammers (1990) indicates, competition exists, but "it is a complex phenomenon that is tied up with cooperation" (p. 182).

In some cases, nonprofit organizations are collaborating to strengthen their competitive position (Bunger 2012; Gazley and Brudney 2007). For example, a survey of Georgia local governments and nonprofits (Gazley and Brudney 2007) indicates that both nonprofits and governments were able to secure additional resources for their respective organizations by engaging in nonprofit-government collaboratives. Many respondents also indicated that collaboration improved the quality of services and programs, increased the level of services, and saved the organization money. Additionally, the rules of the competition may require collaboration. For example, in the US Department of Education's i3 Program, nonprofits can only compete for funds if they are working in collaboration with local education agencies or a consortium of schools. They also collaborate with competitors through coalitions to achieve policy goals that will benefit all. It is beyond the scope of this paper to fully explore the collaboration-competition spectrum, but as I discuss the dimensions of competition I also point out where collaboration and competition are entwined.

\section{Nonprofit Competition Conceptual Framework}

My conceptual framework is based on the notion that nonprofit competition is multi-dimensional, occurs in many arenas, has linkages to government relationships, and is experienced by all types of nonprofit organizations. Nonprofit competition occurs across sectors - government, business, and nonprofit. Nonprofit competition occurs within and across policy areas, that is, nonprofits do not exclusively compete with organizations that are similar in mission. Finally, the scope of competition is broader than generally recognized. Even community-based organizations with local missions may compete on some dimensions against other organizations around the country and around the world.

\section{Overview of Dimensions}

I posit that there are five dimensions of competition: (1) relationships between nonprofits and government, (2) resource types, (3) beneficiary types, (4) types of organizations competing, and (5) scope of competition. These five dimensions interact with each other to create the competition space for each individual 
nonprofit, but cumulatively they create a competition space for the sector as a whole. Following a description of each dimension, I present an exploration of the dimensions by dividing the competition space by the types of resources for which nonprofits are competing, and whether that competition is largely in the private or public marketplace. This yields a discussion of five types of resourcerelationship mixes. A description of the resource-relationship mix, a table depicting dimensions, and one or more examples is provided to illustrate the concept. The five resource-relationship mixes are: competing for resources in the private marketplace (Table 2), competing for beneficiaries (Table 3), competing for government-aligned resources (Table 4), competing for independent resources (Table 5), and competing for hearts and minds.

Throughout the paper I draw on my more than two decades of nonprofit experiences to provide examples of the competition space. Most of those examples are drawn from service in a particular nonprofit organization that began about 40 years ago. Its mission is to ensure affordable, accessible, high-quality child care services for all children and families. During the 15 years that the author worked there, the budget grew from less than $\$ 500,000$ to $\$ 30$ million, the staff grew from fewer than 10 to more than 100, and the service delivery area grew from a single county to the national level. The organization collaborated and competed to garner the resources needed to fulfill its mission. Providing a continuous example helps to show the complexity of competition as it plays out at the organizational level. I add other examples periodically to illustrate diversity of the competitive environment.

\section{Dimension 1: Relationships between Nonprofits and Government}

This resource space is largely defined by government tax policies, but the resources in it may be granted by other organizations, like other nonprofits or businesses. Additionally, it encompasses the aligned, independent, and change relationships with government.

\section{Dimension 1a: Level of Government}

Nonprofits interact with governments at many levels. Here, those levels are represented as local, state, national, and international. Local governments are city, county, school systems, or other regional governments that exist below the state level. State governments represent the 50 U.S. states. The national government is the U.S. government. International governments are those outside of the United States. 


\section{Dimension 2: Resource Types}

These are the types of resources for which organizations are competing. The tables identify various types of inputs - space, equipment, materials, volunteers, staff; funding - contracts, grants, financial donations; and hearts and minds captured through sentiment and attention. The resources may be supplied by governments, but they may also be provided by individuals, foundations, and businesses.

\section{Dimension 3: Beneficiary Types}

Beneficiaries are the recipients of the services provided by the organization. Types of beneficiaries include members, private pay clients, voucher clients, and free service clients.

\section{Dimension 4: Types of Organizations Competing}

This dimension indicates with whom the particular nonprofit is competing. In each table, the types of potential competitors are indicated in the left-hand column. The types of organizations fall into three categories: nonprofits, government, and business. Within the nonprofit and for-profit categories, nonprofits may be competing against other organizations in the same field (i.e. healthcare nonprofits vs. healthcare nonprofit or healthcare for profit) or against organizations in different fields (i. e. healthcare nonprofits vs. child welfare nonprofit or child welfare for profit). Same field and other field are determined by the primary purpose of the organization. The government category has been divided into three areas: public schools, public colleges and universities, and other government.

\section{Dimension 5: Scope of Competition}

The scope of the competition divides the breadth of the competition into three levels: community, national, and international. This scope denotes where the competing organizations are likely to be located. Community refers to the immediate neighborhood(s) in which the organization is located. National refers to larger than the community but within the bounds of the U.S. International refers to any area broader than the United States. 


\section{Exploring the Dimensions}

As discussed, the government-nonprofit relationship may be aligned, independent or change-oriented. A single nonprofit could have all three relationships with a single government organization. Similarly, a single nonprofit could have these relationships across multiple governmental organizations. Additionally, nonprofits compete with each other, with other governments, and with for profits for these relationships with government. The competition space in the relationship with government is constrained by the time, resources, and rules that governments impose on the issues of interest to the nonprofit organizations.

\section{Competing for Resources in the Private Marketplace}

Competition within the private marketplace is largely defined by government tax policies (see Table 2). Businesses, governments, and nonprofits (largely communities of faith) allow other organizations to use their space, equipment, or materials at costs less than the market rate, representing an in-kind contribution. Sometimes businesses allow nonprofit or government organizations to purchase space, equipment, or materials at a reduced price, in-part because of tax benefits that accrue and in-part because of the community good will it creates for them. Similarly, individuals and organizations may offer in-kind or reduced price space, equipment, materials, cash donations and/or volunteers to help nonprofits and government accomplish their work.

Table 2 shows the types of competitors on the left and the types of resource competition across the top. When competing for resources in the private market, nonprofits are competing against other nonprofits in their same field and in other fields (e.g., the resources may be made available to any nonprofit) across the breadth of resources depicted. Competition for in-kind or reduced price equipment and materials occurs at the community, national, and international levels because those goods can be shipped anywhere in the world. A business with headquarters in a particular town may provide donations within that town, but also nationally or internationally depending on the reach of the business.

Competition for staff, however, tends to happen at a community or national level because those are the likely recruitment areas. The competition arenas for direct service staff and back office staff are likely to be somewhat different. Technology and accounting staff exist across all types of organizations and may not select their employer based on mission. This could make it more difficult for 


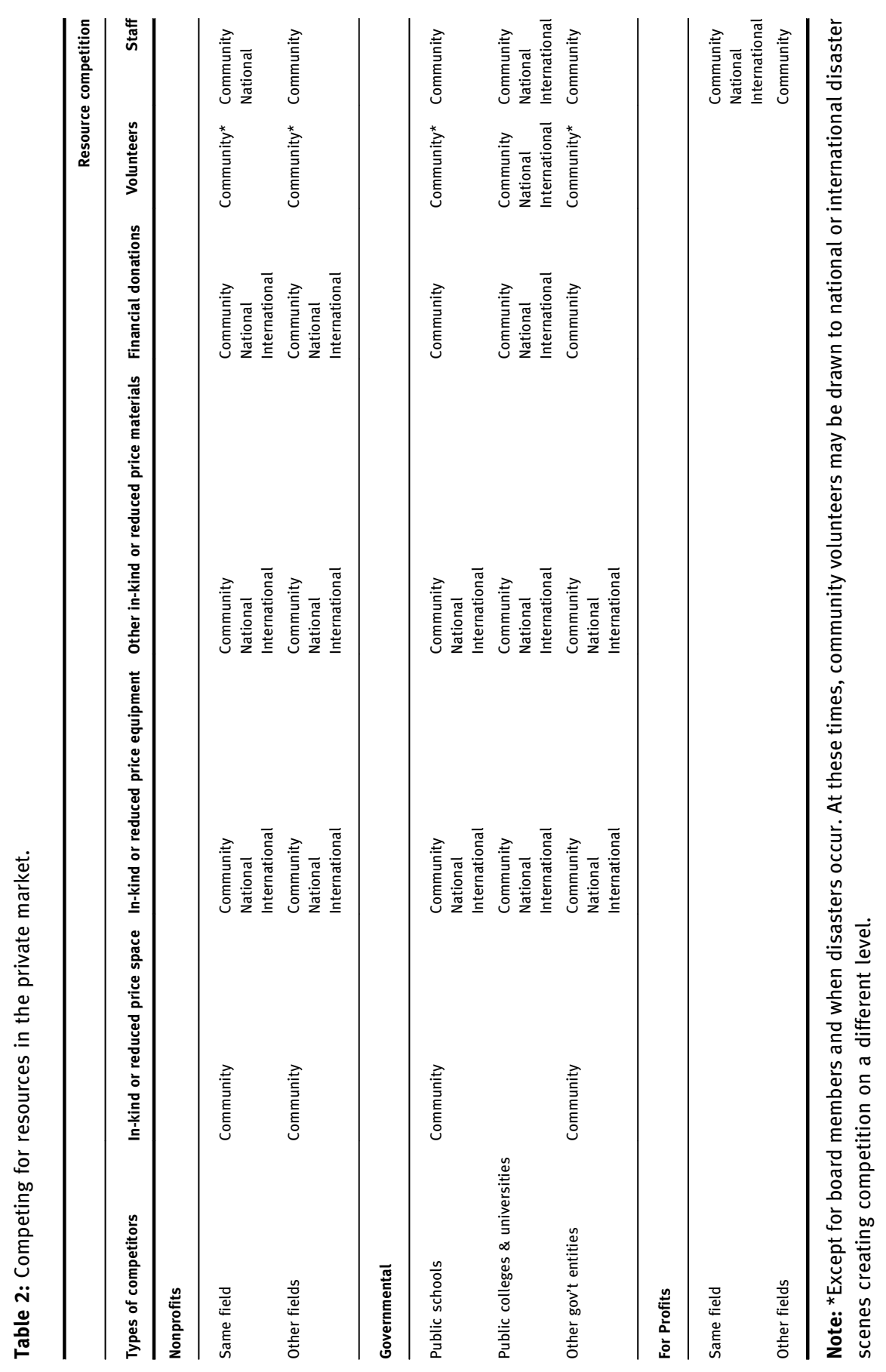


the nonprofit to attract and keep these staff. Direct service staff are likely to have more differentiated expertise and a desire to work in an organization with a particular kind of mission, but that mission focus may be fulfilled by working in any kind of organization with a social purpose - for profit, nonprofit, or government. The more specialized the skill set needed, the fewer organizations the nonprofit is likely to compete with.

The example nonprofit has experienced competition for staff from all sectors. It found it had to change its pay scale and educational requirements to compete with businesses for the kinds of technology support staff that it needed. On the flip side, the nonprofit often found itself in the position of training ground for employees that would later move on to government jobs requiring substantive knowledge in their field. The nonprofit would hire individuals with limited experience, provide them with hands on experience and training, and within a year or two the employees would apply for government positions that required the experience and training they had recently acquired in their nonprofit work.

Competition for in-kind or reduced price space or volunteers tends to be more localized because both space and volunteers tend to be bound to their communities. In times of crisis, however, the competitive market for volunteers expand as many who would normally volunteer locally travel beyond their communities to give their time in places of concentrated, short-term need. Government entities are most likely to compete with nonprofits in their own communities, but public colleges and universities tend to have a broader reach largely because their alumni live all over the world and contribute back to them from where ever that might be. In this private market, for-profit competition is the least, primarily due to tax laws. Entities typically do not receive tax breaks for giving to for-profit organizations which means that competition primarily occurs for staff.

In our example nonprofit, they were at one point expanding, and needed a larger space for operations. They decided they wanted to seek a permanent home. In their search for a building, they found a for-profit company that was seeking to sell its building. The nonprofit was able to negotiate a deal with the for profit that allowed the nonprofit to purchase the building for half its value with the for profit donating the value of the rest. This in-kind donation of space allowed the nonprofit to purchase the building, expand service delivery, and provide services at a lower cost. This space had been for sale on the open market where nonprofit, for profit, or government entities could have purchased it.

In a 2012 Urban Institute survey of human services nonprofits receiving government funds, about half of the survey respondents indicated that they had at least one government grant and about one-quarter reported at least one government contract where they were required to match or share costs; contracts required a $30 \%$ share on average, while grants required a $44 \%$ share on average 
(Pettijohn et al. 2013). Match can sometimes be provided as the value of in-kind or volunteer time to meet the matching requirements. Thus, obtaining these kinds of resources not only allows nonprofits to do their work more costeffectively but helps them to leverage other funding streams.

\section{Competing for Beneficiaries}

Direct beneficiaries (see Table 3) of nonprofit services fall into two primary categories: (1) members who pay dues to receive benefits from the organization or (2) clients/customers who obtain services from the organization. Both categories of beneficiaries may be either individuals or organizations. Clients/ customers of service may access services free of charge, through voucher-based payments, or as private-payers. The competitive market for clients/customers is a bit narrower than it is for the other resources for which nonprofits compete because clients'/customers' needs can only be met by organizations providing services in the same field. Organizations may serve a mix of private-payers, voucher-based, or free clients, or they may specialize in a particular kind of market. Regardless of the kind of client payment arrangement, organizations compete to serve the clients. Voucher-based and private-pay clients bring payments with them on a per-client basis much like what would happen in the private market. Nonpaying clients may not bring payment directly with them, but contracts with funders may have performance standards that require an organization to serve a minimum number of clients to receive full payment for their contract award.

Table 3: Members and clients/customers.

\begin{tabular}{lllll}
\hline & & & & Clients/customers \\
\hline Types of competitors & Members & Free & Voucher-based & Private-payers \\
\hline Nonprofits same field & $\mathrm{X}$ & $\mathrm{X}$ & $\mathrm{X}$ & $\mathrm{X}$ \\
Nonprofits other fields & $\mathrm{X}$ & & & \\
For profits same field & & $\mathrm{X}$ & $\mathrm{X}$ & $\mathrm{X}$ \\
Government same field & & $\mathrm{X}$ & $\mathrm{X}$ & $\mathrm{X}$ \\
\hline
\end{tabular}

In our example organization, they provided a free referral service for families looking for child care. The largest funder of these services reviewed service levels and spending levels mid-way through the fiscal year. If either spending or client counts were low, then contract dollars may be withdrawn. 
The competitive market for members encompasses both same and other fields, but it is limited to associations, which are by definition nonprofits. For example, an individual may have multiple interests supported by multiple associations, but the individual cannot afford to be a member of every association that might be helpful. The individual must choose which associations to join in order to fit within his/her budget constraint, and therefore associations must compete across fields for members.

\section{Aligned Relationships}

An aligned relationship between nonprofits and governments occurs when governments cannot provide enough of the service they identify as a need. For example, the government may have a waiting list for their child care subsidy assistance program that is designed to help low-income parents pay for child care so that those parents can go to work while their children are in a safe environment. Nonprofits with a similar mission may seek government funds to provide more of that same service targeting the same population with the same eligibility requirements, but serving the families that are on the waiting list for government services. Those nonprofits may be able to bring funds from other sources to the service delivery. In this way, the nonprofit collaborates with government by offering to help meet its service goals but has to compete with other organizations to obtain the funds to complement the service.

An aligned relationship between nonprofits and governments also exists when government contracts with a nonprofit to replace what had been governmentdelivered services. Government may determine that delivering the service directly is less efficient or effective than contracting with another organization to deliver it.

Our example nonprofit works to complement the state/federal child care subsidy funds by garnering additional funding from the United Way, local government grants, other funding sources, and individual donations. That organization runs its own child care subsidy program and uses some of the funds to serve individuals waiting for the state/federal child care subsidy funds enabling more individuals to receive county-equivalent benefits. This nonprofit organization collaborates with government to deliver the aligned services, but they must compete with other organizations to obtain the resources and they must compete with other organizations, including governments, to administer the services.

The competition for government funding to provide these aligned and replacement services is indicated by Table 4. Nonprofits seeking government grants have to compete with other nonprofits. Grants are typically awarded to nonprofit organizations, but a contract mechanism is more likely to be used 
when the government wants to obtain complementary services from for profit or other government entities. Contracts for aligned or replacements services would have to be with organizations providing services in the same field. However, some of the organizations may provide services across many fields.

Table 4: Competition for government-funded* service delivery grants and contracts that complement (are aligned with) or replace government services.

\begin{tabular}{llll}
\hline & & Resource competition \\
\hline Types of competitors & $\begin{array}{l}\text { Complement } \\
\text { grants }\end{array}$ & $\begin{array}{l}\text { Complement } \\
\text { contracts }\end{array}$ & $\begin{array}{l}\text { Replacement } \\
\text { contracts }\end{array}$ \\
\hline $\begin{array}{l}\text { Nonprofits same field } \\
\text { Nonprofits other fields }\end{array}$ & $\mathrm{X}$ & $\mathrm{X}$ & $\mathrm{X}$ \\
$\begin{array}{l}\text { For profits same field } \\
\text { Government same field }\end{array}$ & $\mathrm{X}$ & $\mathrm{X}$ & $\mathrm{X}$ \\
\hline
\end{tabular}

Note: *Nonprofits may also compete for funding from nongovernmental sources to complement the government services.

\section{Independent Relationships}

While providing enough of the government-defined services is important for the population that needs those services, those government-defined parameters typically target some populations and activities and leave other populations and activities out. Nonprofits typically fill service needs not met by government. These kinds of services are characterized as independent of government services. Other independent nonprofit activities include knowledge-building, innovation, and civic engagement.

Independent services may be very similar to government services, but expand the populations served (e.g. by age, income, type of disability, etc.) or provide additional services to those receiving the government support. Independent services may also be completely different from what the government is already doing but help the community and society to innovate, build knowledge, and facilitate civic engagement (see Table 5).

Our example nonprofit also seeks out resources that allow families not eligible for government-supported child care subsidy funds to access other forms of assistance. The government-administered funds are constrained by income eligibility guidelines that are set statewide. One of the counties the nonprofit serves has a high cost of living which means that families become ineligible for government-provided help at an income level that is not sufficient to support their child 
Table 5: Competition for grants or contracts that supplement government services.

\begin{tabular}{|c|c|c|c|c|c|}
\hline \multirow[b]{2}{*}{$\begin{array}{l}\text { Types of } \\
\text { competitors }\end{array}$} & \multirow[b]{2}{*}{$\begin{array}{l}\text { Expand populations } \\
\text { served }\end{array}$} & \multicolumn{4}{|c|}{ Competing for resources to deliver services } \\
\hline & & $\begin{array}{l}\text { Special services } \\
\text { to special } \\
\text { populations }\end{array}$ & Innovation & $\begin{array}{l}\text { Knowledge } \\
\text { building }\end{array}$ & $\begin{array}{l}\text { Civic } \\
\text { engagement }\end{array}$ \\
\hline \multicolumn{6}{|l|}{ Nonprofits } \\
\hline Same Field & $\mathrm{x}$ & $\mathrm{x}$ & $x$ & $\mathrm{x}$ & $\mathrm{x}$ \\
\hline Other Fields & $\mathrm{x}$ & $x$ & $\mathrm{x}$ & $\mathrm{x}$ & $\mathrm{x}$ \\
\hline \multicolumn{6}{|l|}{ Government } \\
\hline $\begin{array}{l}\text { Public } \\
\text { Colleges \& } \\
\text { Universities }\end{array}$ & $x$ & $\mathrm{x}$ & $x$ & $x$ & \\
\hline $\begin{array}{l}\text { Public } \\
\text { Schools }\end{array}$ & & $\mathrm{x}$ & $x$ & $\mathrm{x}$ & $x$ \\
\hline \multicolumn{6}{|l|}{ For Profits } \\
\hline Same Field & $x$ & $\mathrm{x}$ & $x$ & $x$ & \\
\hline Other Fields & $x$ & $x$ & $x$ & $x$ & \\
\hline
\end{tabular}

care needs. The nonprofit and county government collaborate to transition families from the government-administered program to the nonprofit-administered program when family incomes reach the tipping point.

Schools are an obvious place that nonprofits build knowledge. Charter schools supplement public school services by providing alternative choices to families and children. Other kinds of nonprofits, however, also build knowledge by testing out and documenting particular service delivery methods, participating in evaluations, and building an evidence base for development and delivery of future services. The Urban Institute represents a type of organization that builds knowledge by conducting research and sharing the results with the public. Knowledge-builders must compete with similar and dissimilar organizations for funds to conduct their research, evaluation, and dissemination or teaching. Sometimes they collaborate with each other to strengthen their competitive position. They compete and collaborate cross the sectors.

Nonprofits also compete to innovate. Governments often benefit from these innovations. As discussed earlier, sometimes governments sponsor the competitions that lead to innovation. In other cases, they may adopt innovations once they are proven to work. 
Our example nonprofit developed a pilot project with the aid of a local foundation to improve child care teacher education. Once the nonprofit demonstrated improved educational outcomes from the pilot, the state government provided funding to expand the program statewide. Over the years, the community-based nonprofit collaborated with other nonprofit organizations and governments around the country to spread the innovation. Twenty years after the pilot, the program is operating in 23 states and the District of Columbia (CCSA 2011-12 Annual Report).

Finally, nonprofits compete to promote civic engagement experiences for children, youth, and adults. In this case, I am not talking about advocacy but rather encouraging individuals to participate on government boards and committees, to vote, and to otherwise help in their community. For example, the John S. and James L. Knight foundation provided between 90 and 206 grants per year between 2005 and 2013 to foster "engaged communities" (see web-page: http://www. knightfoundation.org/grants/?focus_area=3).

\section{Change-Oriented}

The competition for the hearts and minds of the media, the public, and government officials is the dimension of the nonprofit-government relationship characterized as change-oriented. This relationship is one where nonprofits identify changes that they feel need to be made in the way that government operates to better serve the community in particular ways. The changes may be in the amount of resources allocated, the strategies for meeting needs, and the laws, policies, and procedures that dictate how needs are defined or how they are met. While nonprofits are working to change government actions, they may be educating the media, the public, and elected and administrative officials about the issues and then working with the government for change. Some government policies may be changed administratively, and therefore gaining the attention of civil servants is important for making change. Some government policies can only be changed through votes of elected bodies such as town councils, county commissioners, state legislatures, regulatory bodies or Congress. In these cases, the attention of elected officials is needed to make change.

The advocacy space requires nonprofits to compete with each other, governments, and for profits for the hearts, minds, and attention of the media, the public, and government officials. Communities have many important needs, and limited resources to address them. Thus, competition occurs around framing the needs, prioritizing resource allocation, and in determining strategies. The resource that is the object of competition is framed as attention or sentiment. 
This is because gaining the attention of elected or administrative officials or the media is the first step in having issues understood and acknowledged. Attention also refers to the time spent on digging into the issues, networking with colleagues to put items on agendas, and in crafting legislative or allocation language for the consideration of peers. Similarly, public action begins with garnering public sentiment to promote the issues through the media and direct interactions with government officials. Thus, nonprofit competition for attention and sentiment may motivate civic participation around policy and budget issues.

All types of nonprofits, government, and for profits compete together in the same space. Depending on the particular forum or level of government where the decision must be made, the competition may be primarily limited to the community, state, or national levels. However, most media cover issues that span the breadth of community to international, and the public is often paying attention to issues across that same breadth. So, while efforts of competitors may be concentrated in particular communities, they are still competing for attention and sentiment on an international basis.

Despite the important role that nonprofits play in advocating for societal change, nonprofits are constrained in their advocacy efforts based their particular nonprofit tax status. Government rules define the kinds of advocacy in which they can engage, what percent of their budget can be used for that activity, and whether government funds the nonprofit received may be used for that activity at all.

Groups are also coming together as coalitions to foster greater leverage of their own time and voices in larger policy discussions which helps nonprofits offset the limitations imposed by their tax status. These groups may span across nonprofit, for-profit, and government organizations. The nonprofit I have been following throughout this paper participates in a number of coalitions, but is an active member in a particular coalition that works on behalf of the children, families, and child care operators that are the primary beneficiaries of the nonprofit. That coalition consists of nonprofit and for-profit businesses. The nonprofits have a focus on child care, consumer financial services, individuals with disabilities and mental health issues, and the elimination of poverty. Many of these organizations have been working together for more than 30 years to advocate on behalf of children and families.

\section{Concluding Thoughts on Dimensions of Competition}

This exploration of the dimensions and types of competition suggests that many nonprofits engage in competition on a daily basis. Just like for-profit organizations, 
nonprofits must compete for customers (beneficiaries), inputs (labor and capital), investors (funders and individual donors), and for the hearts and minds of the government officials that allocate resources and make policy decisions, the media that frames the story, and the public that can stimulate discussion and action. Nonprofits face many of the same competitive challenges as for profits including an expanding scope of competition in which even organizations that seek only to provide neighborhood-based services must compete globally.

Nonprofits also face many of the same challenges as government. They deliver government-defined services alongside or as a replacement to government delivery. Like government, they face the challenge of pricing these services, and determining how to provide services for individuals who cannot pay but who fall within the parameters of mission. Like government, they must meet standards other than efficiency and financial return-on-investment.

The combined need to compete like businesses and to function like government has implications for the management and board governance of individual nonprofits, the roles of nonprofits in society, and the nonprofit-government relationship. Nonprofits must juggle societal expectations of what it means to be nonprofit, while competing to secure market and funder-mediated resources. At the same time, they are independent operations with their own missions, goals, and constituencies to serve. Additionally, they do not enjoy the same avenues for raising revenues as either governments or for-profit businesses. What are the implications of this competition space for nonprofits, the communities they serve, and their relationship with government? Next, I suggest some areas for future research in this regard.

\section{Implications of Competition for Nonprofit-Government Relationships}

Frequently, the implications of competition for government are viewed through the instrumental lens that suggests that more competition is always better because it will bring more efficient, more effective services through government contracts. That lens, however, focuses on the aligned relationship to government only. It is an important public value for government to secure the best services at the best cost, and in the for-profit realm competition is the way to accomplish this goal. This view, however, leaves out the other ways that nonprofits bring value to government and to our society more broadly. How else should we examine the implications of competition? 
In this paper, I describe competition occurring across sectors, across many types of resources, and as frequently extending beyond communities. Based on experience, we know that these kinds of competitions exist, but we do not know to what extent they exist, under what circumstances they are likely to exist, how these competitions affect nonprofits more broadly, and the effects of these kinds of competitions on nonprofits, their communities, and the people they serve.

For example, much research on nonprofit competition focuses on the numbers of nonprofits within a geographic area. This paper suggests that while geography has some bearing, competition is dispersed more broadly than the locality in which a nonprofit is located. Globalization of companies and the ease of donating through the Internet broadens the bounds of competitions that once were local.

How has globalization of companies affected the nonprofit competition space? To what extent are nonprofits competing across communities and across countries for corporate resources?

To what extent does the ability of individuals to donate to nonprofits anywhere in the world affect the local share that nonprofits receive? Does it vary by community, type of nonprofit services, etc.?

When crises happen, we regularly hear on the news about volunteers mobilizing in one community to help out another community, state, or nation. We also see reports of the crisis community receiving in-kind donations of materials from all over the world. Acts of compassion crossing geographic borders uplift the human spirit and contribute in their own ways to enhancing society, but what implications do these actions have for nonprofits in the home communities from which the volunteers and gifts flow?

Do crises elicit more giving or do they create a substitution effect that the local communities must absorb? Do the effects vary by type, magnitude, or duration of the crisis, or by proximity of the crisis to the home community? How does competition induced by crisis differ from everyday competition?

Recognizing that the value of nonprofits extends beyond their service delivery functions, what types of spillover effects (good or bad) does competition have for the ability of nonprofits to innovate, to develop and deliver knowledge, and to engage citizens in building civil society? To what extent do the effects vary by field or type of competition? To what extent do the effects vary by the density or intensity of competition? In what ways do tax policies contribute to this type of competition?

What are the implications of competition for the hearts and minds, for attention and sentiment? What are the linkages between tax policies and the ability to compete in this sphere? What are the spillover effects for beneficiaries of services? 
Finally, what are the implications of competition for board composition, board governance, and managerial skills and experience? Both boards and management staff must have the capacity to balance mission and competition; what skills and strategies are best suited for doing so?

These questions are just the tip of the iceberg of what could be learned if we study nonprofit competition systematically. Although thinking about nonprofits as competitors is not a traditional viewpoint, only research can tell us if competition within the nonprofit sector and across the sectors is good or bad for society. Studying competition through its dimensions and relationships with government could help us to understand the circumstances under which competition fosters benefits or creates consequences for society. Further, understanding the linkages between tax policies, and the advantages/disadvantages they create for nonprofits in a competitive marketplace may foster more informed policy-making in the future.

\section{References}

Bunger, A. 2012. "Administrative Coordination in Nonprofit Human Service Delivery Networks: The Role of Competition and Trust." Nonprofit and Voluntary Sector Quarterly XX (X):1-21. Business Master File. 2013. National Center for Charitable Statistics.

Engaged Communities. John S. \& James L. Knight Foundation: Accessed May 4, 2015. http://www.knightfoundation.org/what-we-fund/engaging-communities

Frumpkin, P., and A. Andre-Clark. 2000. "When Missions, Markets, and Politics Collide: Values and Strategy in the Nonprofit Human Services." Nonprofit and Voluntary Sector Quarterly 29 (1 supplement): 141-163.

Gazley, B., and J. Brudney. 2007. "The Purpose (and Perils) of Government-Nonprofit Partnership." Nonprofit and Voluntary Sector Quarterly 36 (3):389-415.

Kincaid, J. 1991. "The Competitive Challenge to Cooperative Federalism: A Theory of Federal Democracy." In Competition Among State and Local Governments, edited by D. Kenyon and J. Kincaid, 87-114. Washington, DC: Urban Institute Press.

Lammers, J. 1990. "The Effect of Competition on Labor Management in Nonprofit Organizations." Nonprofit and Voluntary Sector Quarterly 19 (2):171-86.

Osbourne, D., and T. Gaebler. 1992. Reinventing Government: How the Entrepreneurial Spirit Is Transforming the Public Sector. New York: The Penguin Group.

Pettijohn, S., E. Boris, C. De Vita, and S. Fyffe. 2013. Nonprofit-Government Contracts and Grants: Findings from the 2013 National Survey. Washington, DC: The Urban Institute.

Weisbrod, B. 1997. "The Future of the Nonprofit Sector: Its Entwining with Private Enterprise." In The Nature of the Nonprofit Sector second edition, edited by J. S. Ott and L. A. Dicke Boulder, CO: Westview Press 348-366.

Wiemer, D., and A. Vining. 2005. Policy Analysis: Concepts and Practice, 4th ed. Upper Saddle River, NJ: Pearson, Prentice Hall.

Young, D. 2006. "Complementary, Supplementary or Adversarial? Nonprofit-Government Relations?" In Nonprofits \& Government: Collaboration \& Conflict, 2nd ed., edited by E. Boris and C. E. Steuerle Washington, DC: The Urban Institute Press 37-79. 